\title{
AMPLA DEFESA E ADEQUADA INSTRUÇÃO PROBATÓRIA EM PROCESSO DISCIPLINAR INSTAURADO CONTRA MAGISTRADO
}

\author{
CÁNDIDO AlfRedo Silva LEAL JÚNIOR \\ "O tu che vieni al doloroso ospizio", \\ disse Minòs a me quando mi vide, \\ lasciando l'atto di cotanto offizio. \\ "guarda com' entri e di cui tu ti fide: \\ non t'ingannil'ampiezza de l'intrare!"
}

(Dante, Inferno, V, 16-20).

I - Introdução; II - O direito à defesa ampla: III - Limites à acusação no processo disciplinar; IV - Interrogatório do acusado; $V$-I Inquirição de testemunhas de defesa; VI - Direito à sustentação oral; VII - Direito de presença na sessão de julgamento; VIII - Nulidade do processo disciplinar; IX - Fim das sessões secretas.

\section{$I$ - Introdução}

Talvez soe óbvio, desnecessário ou exagerado um texto sobre os direitos de ampla defesa e de adequada instrução probatória em processos disciplinares instaurados contra magistrados. Para aqueles que conhecem de perto as falhas e os excessos nos mecanismos de controle interno no Judiciário Brasileiro, todavia, é válida a advertência feita pelo guardião do Inferno a Dante, quando este lá ingressava: "non t'inganni l'ampiezza de l'intrare".

A idéia de que "os juízes é que são os principais inimigos da independência da magistratura" não é do autor desse artigo, mas de muitos juristas de destaque ${ }^{1}$, que

1 Nesse sentido, por todos que defendem essa idéia, basta mencionar DALLARI, Dalmo de Abreu. O Poder dos Juizes. São Paulo: Saraiva, 1996. p. 45. 
conhecem de perto e estudam a fundo a estrutura do Judiciário Brasileiro e não temem abertamente professar sua crença na necessidade de alterações profundas nesses mecanismos, evitando favoritismos, perseguições e impunidades.

Não há dúvida que são necessários instrumentos de controle interno da atividade jurisdicional, assegurando à sociedade e aos interessados que a independência e imparcialidade dos juízes sejam preservadas e aperfeiçoadas. O processo disciplinar, aliás, é um dos poucos instrumentos que a sociedade dispõe contra os maus juízes. Suas únicas finalidades devem ser, assegurar a disciplina no serviço judiciário, assegurar que os magistrados não abandonem sua função de órgãos públicos a serviço da causa da justiça e da democracia, e assegurar que os magistrados cumpram seus deveres legais e constitucionais ${ }^{2}$.

Mas o controle é interno e os Tribunais insistem que seja secreto. Ou seja, é realizado por outros magistrados, com suas paixões, seus vícios, suas idiossincrasias, tudo protegido pelo manto do segredo.

Tramitando em segredo, às escondidas, muitas vezes esses instrumentos de controle interno se transformam em espaço para perseguição ideológica, subjetivismos, arbitrariedades e até mesmo impunidade. O que não poderia acontecer, acaba acontecendo: os instauradores e condutores do processo esquecem as finalidades reais do controle interno, utilizando-o então com motivações ideológicas ou corporativas, seja para perseguir magistrados independentes, seja para proteger colegas desidiosos. O fato é que ser instaurado e conduzido por magistrados não assegura nele a realização da justiça ou o respeito aos direitos constitucionais do magistradoacusado ${ }^{3}$.

Pensando nisso e considerando as lacunas da legislação adjetiva e substantiva que trata de processos disciplinares instaurados contra magistrados, o Fórum Permanente de Corregedores da Justiça Federal, sob coordenação do Conselho da Justiça Federal do Superior Tribunal de Justiça, propôs o regramento das hipóteses de instauração de processo disciplinar contra magistrados ${ }^{4}$.

2 Nesse sentido, "a efíciência do controle interno da Magistratura, aliada a um adequado processo de seleção e de aperfeiçoamento dos juízes, consubstancia segura fórmula, segundo se crê, para uma melhor prestação do serviço jurisdicional" (GODOY, Cláudio Luiz Bueno de. Responsabilidade Disciplinar dos Juizes. Controle Interno da Magistratura. In: FREITAS, Vladimir Passos de (organizador). Corregedorias do Poder Judiciário. São Paulo: Revista dos Tribunais, 2003, p. 65). 3 Nesse sentido, diz o dito popular: "casa de ferreiro, espeto de pau" ... Isso fica evidenciado pela suspeição com que é vista uma jurisdição doméstica, com que é tratada a responsabilização disciplinar dos magistrados: " tale forma di responsabilità, su cui peraltro l'informazione è pressoché inesistente. quando non volutamente distorta, viene configurata como esempio inaccettabile di giurisdizione domestica, espressione della 'casta' dei magistrati, mantenuta in vita próprio allo scopo di fornire um simulacro di giustizia, Che metta al riparo i giudici da altre forme più serie e concrete di responsabilità" (MELE, Vittorio. La responsabilità disciplinare dei magistrati. Milano: Giuffré, 1987, p. 01).

4 Cfe. NOTÍCIAS DO SUPERIOR TRIBUNAL DE JUSTIÇA. Cesar Asfor Rocha reine corregedores no Conselho da Justiça Federal. Edição do Superior Tribunal de Justiça em 16.12.02. Disponível em: 'www.stj.gov.br'. Acesso em: 05.03.03. 
Dada a importância do tema e a necessidade de observância de um devido processo administrativo, prévia e objetivamente estabelecido, evitando-se a impunidade daqueles que devam ser punidos ou a perseguição àqueles que tão-somente se mostraram independentes no desempenho de suas funções jurisdicionais, vem em boa hora a disciplina da matéria pelo órgão central do Poder Judiciário Federal.

O objetivo desse modesto texto é contribuir para esse debate, levantando algumas questões práticas a respeito do direito de ampla defesa e de adequada instrução probatória no âmbito das sindicâncias e processos administrativo-disciplinares instaurados contra magistrados federais.

\section{$I I$ - O direito à defesa ampla}

(a) Natureza do processo disciplinar contra magistrados:

O processo administrativo-disciplinar é "o meio de apuração e punição de faltas graves dos servidores públicos e demais pessoas sujeitas ao regime funcional de determinados estabelecimentos da Administração"s. Nosso texto se interessa por uma modalidade específica de processo disciplinar, que é aquele em que figura como acusado um magistrado, submetido a regime disciplinar próprio, previsto nos arts. 93 e 95 da CF/88 e na Lei Orgânica da Magistratura.

Mesmo que instaurado contra magistrado, ainda aqui tem-se um procedimento administrativo, no qual são praticados atos administrativos tendentes à apuração de infração funcional e à aplicação de sanção disciplinar, submetendo-se aos regramentos próprios do direito administrativo, conforme já decidido pelo próprio Supremo Tribunal Federal ${ }^{6}$.

Consistindo em atuação administrativa vinculada, esses processos disciplinares submetem-se àqueles princípios do art. 37, caput da $\mathrm{CF} / 88$, dentre os quais destacam-se a legalidade, impessoalidade, moralidade, publicidade e eficiência. Por isso, os magistrados que instauram, conduzem e julgam esse processo não o fazem por vontade própria nem devem se utilizar desse instrumento para atender caprichos pessoais ou sentimentos corporativos. Ao contrário, trata-se de competência constitucional vinculada a uma finalidade específica (preservação e aprimoramento do

5 Cfe. MEIRELlES, Hely Lopes. Direito Administrativo Brasileiro. $18^{\mathrm{a}}$ edição. São Paulo: Malheiros, 1993, p. 594.

6 Nesse sentido, "cumpre ter presente que o Estado, em tema de punições de índole disciplinar ou de caráter político-administrativo, não pode exercer a sua autoridade de maneira abusiva ou arbitrária, desconsiderando, no exercício de sua atividade censória, o princípio da plenitude de defesa, pois - não custa enfatizar — o reconhecimento da legitimidade ético-jurídica de qualquer sanção punitiva imposta pelo Poder Público exige, ainda quando se cuide de procedimento meramente administrativo (CF, art. $\left.5^{\circ}, \mathrm{LV}\right)$, a fiel observância do princípio do devido processo legal, consoante adverte autorizado magistério doutrinário" (SUPREMO TRIBUNAL FEDERAL, AO 487/AM. rel. Min. Celso de Mello, julgado em 10.07.97, DJU-I de 01.08.97). 
serviço judiciário e observância dos deveres do cargo de magistrado) ${ }^{7}$, integrando as prerrogativas de autogoverno do Poder Judiciário e com base nisso devendo serem exercidas. 8

Ainda sobre a natureza do processo administrativo-disciplinar, como referiu o Conselho da Justiça Federal por ocasião da edição de seu Manual do Processo Administrativo Disciplina ${ }^{*}$, o direito administrativo disciplinar guarda relação com o direito penal, sendo então aplicáveis as regras do direito penal e do direito processual penal subsidiariamente ao processo disciplinar e à apuração de sanções disciplinares.

Efetivamente, "se o Direito Administrativo Disciplinar possui mesmo alguma afinidade, esta define-se perfeitamente com a identidade do direito de punir, e este somente se encontra em duas esferas: na criminal e na administrativa" ${ }^{10}$, de onde a conclusão de que "o que ocorre no Direito Processual Penal, no concernente aos atos, termos e até mesmo, sob certo aspecto, aos prazos ocorre substancialmente no Direito Administrativo Disciplinar. O processo tem o seu rito especial, ordinário ou sumário, e este apresenta uma semelhança extraordinária com o Direito Processual Penal, embora não resguarde, às vezes, as mesmas expressões expressas" 11 .

\section{(b) Direito de ampla defesa do magistrado-acusado:}

Afirmada a submissão do processo disciplinar contra magistrado ao regramento próprio de direito administrativo, não restam dúvidas de que o magistrado-acusado tem direito à ampla defesa, com os meios e recursos a ela inerentes, somente assim sendo legitimada a imposição de eventual sanção disciplinar ${ }^{12}$. Não é a autoridade

7 Nesse sentido, "é preciso ter em conta, quando se está diante da atividade administrativo-disciplinar, mesmo envolvendo juízes, que o objetivo perseguido é a preservação da efíciência e ainda a melhora do serviço, a que a punição do faltoso serve de meio, pura e simplesmente" (GODOY, Cláudio Luiz Bueno de. Responsabilidade Disciplinar dos Juízes. Controle Interno da Magistraitura. In: FREITAS. Vladimir Passos de (organizador). Corregedorias do Poder Judiciário. São Paulo: Revista dos Tribunais, 2003, p. 75).

\& Cfe. art. 96-I-b da CF/88, que dispõe: “compete privativamente ... aos tribunais ... organizar suas secretarias e serviços aluxiliares e os dos juízos que lhes forem vinculados, velando pelo exercício da atividade correcional respectiva" (grifou-se).

9 Cfe. PODER JUDICIÁRIO. Conselho da Justiça Federal. Manual do Processo Administrativo Disciplinar. Brasília: Conselho da Justiça Federal, 1990, p. 03.

10 Cfe. LUZ. Egberto Maia. Direito Administrativo Disciplinar (teoria e prática). $2^{a}$ edição. São Paulo: Revista dos Tribunais. 1992, p. 74.

11 Cfe. LUZ, Egberto Maia. Direito Administrativo Disciplinar (teoria e prática). $2^{a}$ edição. São Paulo: Revista dos Tribunais, 1992, p. 80.

12 Não há nisso nenhuma novidade, porque Ada Pellegrini GRINOVER já em 1984 defendia. muito antes da Constituição Federal de 1988, que o direito à ampla defesa deve ser assegurado em todos os processos administrativo-disciplinares, porque "numa visão não estritamente jurisdicional, mas processual, abrangente, portanto, não apenas dos processos que são instrumento da atuação jurisdicional, mas, também, de outros processos ('procedimentos') em que se garanta o direito de defesa, não se pode deixar de lado o processo administrativo disciplinar a que, muito embora não 
dos julgadores que confere legitimidade à punição disciplinar, mas a observância do devido processo administrativo, com respeito aos direitos processuais e funcionais do magistrado-acusado. Somente quando se percorre todo o caminho do processo disciplinar, com respeito aos direitos do acusado, é que a penalidade disciplinar pode ser aplicada e subsiste juridicamente ${ }^{13}$.

Mas nem sempre foi assim. O que hoje é óbvio e inquestionável, não o era no passado. O direito administrativo evoluiu por um longo e tortuoso caminho até que se reconhecesse aquilo que hoje sequer mais é questionado: ainda que em procedimento administrativo, o acusado tem direito subjetivo à ampla defesa ${ }^{14}$.

Alguns ainda ousam ver nos direitos do acusado um obstáculo que dificulta a atividade disciplinar ${ }^{15}$. Todavia, esses esquecem princípios caros aos estados democráticos de direito, como a ampla defesa, a presunção de inocência, o direito à dilação

haja exercício de função jurisdicional, se aplica a garantia constitucional, expressa, do direito de defesa. É claro que o direito de defesa e contraditório, no processo administrativo disciplinar. não se restringem à tutela dos interesses dos funcionários "stricto sensu". mas se estendem a todos os servidores, qualquer que seja o regime jurídico a que se sujeitem. e desde que haja possibilidade de aplicação de sanção disciplinar" (GRINOVER, Ada Pellegrini. O processo em sua unidade -. II. Rio de Janeiro: Forense, 1984, pp. 64-65, grifou-se).

13 Nesse sentido, "cumpre ter presente que o Estado, em tema de puniçōes de índole disciplinar ou de caráter político-administrativo, não pode exercer a sua autoridade de maneira abusiva ou arbitrária, desconsiderando, no exercício de sua atividade censória, o princípio da plenitude de defesa, pois - não custa enfatizar --, o reconhecimento da legitimidade ético-jurídica de qualquer sançāo punitiva imposta pelo Poder Público exige, ainda que se cuide de procedimento meramente administrativo (CF, art. $\left.5^{\circ}, \mathrm{LV}\right)$, a fiel observância do princípio do devido processo legal, consoante adverte autorizado magistério doutrinário" (SUPREMO TRIBUNAL FEDERAL, Ação Originária 487-0/AM, rel. Min. Celso de Mello, DJU-I 1.8.97, p. 33.523).

14 Nesse sentido, houve evolução no reconhecimento da garantia da ampla defesa alcançar não apenas o processo penal, mas também o processo disciplinar (FERREIRA. Sérgio de Andréa. $A$ garantia da ampla defesa no direito administrativo processual disciplinar. Revista de Direito Público, ano V, volume 19, janeiro a março de 1972, pp. 60-68). Efetivamente. "não é, apenas, no processo jurídico penal que há acusados: estes estão presentes, também, em processos administrativos, entre eles, o processo administrativo disciplinar". sendo de se acentuar a ocorrência da chamada jurisdicionalização do procedimento administrativo, "isto é, a recepção, pelo mesmo, de princípios e regras do processo judicial. notadamente no que se refere às garantias de defesa, tornando-o, sem tirar-lhe a natureza de autocomposição, o mais justo possível, na pesquisa da verdade" (FERREIRA, Sérgio de Andréa. A garantia da ampla defesa no direito administrativo processual disciplinar. Revista de Direito Público, ano V, volume 19, janeiro a março de 1972, pp. 61-62).

15 Nesse sentido, fica implícita essa idéia de que os direitos do acusado são obstáculos à sua punição, por exemplo, em respeitáveis obras da doutrina nacional: " $(\ldots)$ a jurisdicionalização sob cujo manto se vem enxergando a atividade disciplinar, se indiscutível, até mercê do comando do art. $5^{\circ}, \mathrm{LV}$, da CF, quando se cuida de garantir os princípios do contraditório e da ampla defesa, em especial nos procedimentos administrativos disciplinares, não pode levar a que se perca de vista aquela específica finalidade da responsabilização disciplinar, nada relacionada com a repressão penal ou com o fundamento de sua imposiçāo" (GODOY, Cláudio Luiz Bueno de. Responsabilidade Disciplinar dos Juizes. Controle Interno da Magistratura. In: FREITAS, Vladimir Passos de (organizador). Corregedorias do Poder Judiciário. São Paulo: Revista dos Tribunais, 2003, p. 75). 
probatória, a imparcialidade do julgador etc. Mesmo assim, não resta mais espaço para qualquer dúvida: "em qualquer processo em que haja acusado, deve haver ampla defesa" 16 .

O direito constitucional brasileiro passou por uma longa transformação, principalmente em decorrência do processo de abertura e redemocratização, onde velhas estruturas autoritárias foram substituídas por regramentos próprios de um estado democrático de direito, inserindo-se nessa transformação uma nova concepção da processualidade no âmbito da função administrativa, "seja para transpor para a atuação administrativa os princípios do devido processo legal, seja para fixar imposições mínimas quanto ao modo de atuar da administração". conforme adequadamente retratado por Ada Pellegrini GRINOVER. ${ }^{17}$

Então não há como negar ao magistrado-acusado direito à ampla defesa no processo administrativo-disciplinar contra ele instaurado, já que ele é um acusado ${ }^{18}$, já que se trata de um processo administrativo ${ }^{19}$, e já que a legislação pertinente assim prevêt

16 Cte. GRINOVER, Ada Pellegrini. O Processo em Evolução. Rio de Janeiro: Forense Universitária, 1996, p. 82, grifou-se

17 Nesse sentido, "as garantias do contraditório e da ampla defesa, para o processo não-penal e para os acusados em geral. em processos administrativos, já eram extrádas. pela doutrina e pela jurisprudênciat, dos textos constitucionais interiores, tendo a explicitação da Lei Maior em vigor natureza didática, afeiçoada à boà técnica, sem apresentar conteúdo inovador. Mas agora a Constituição também resguarda as referidas garantias aos litigantes, em processo administrativo. E isso não é casual nem aleatório. mas obedece à profunda transformação que a Constituição operou no tocante à função da administração pública. Acolhendo as tendências contemporâneas do direito administrativo, tanto em sua finalidade de limitação ao poder e garantia dos direitos individuais perante o poder, como na assimilação da nova realidade do relacionamento Estado-sociedade e de abertura para o cenário sociopolítico-econômico em que se situat, a Constituiçāo pátria de 1988 trata de parte considerável da atividade administrativa, no pressuposto de que o caráter democrático do Estado deve influir na configuração da administração, pois os princípios da democracia não podem se limitar a reger as funções legislativa e jurisdicional, mas devem também informar a função administratival. Nessa linha, dá-se grande ênfase. no direito administrativo contemporâneo, à nova concepçāo da processualidade no âmbito da funçāo administrativa, seja para transpor para a atuação administrativa os princípios do 'devido processo legal'. seja para fixar imposiçōes mínimas quanto ao modo de atuar da administração" (GRINOVER, Ada Pellegrini. O Processo em Evolução. Rio de Janeiro: Forense Universitária, 1996, pp. 82-83).

18 Cfe. art. $5^{\circ}-\mathrm{LV}$ da CF/88, estabelecendo que "aos litigantes, em processo judicial ou administrativo, e aos acusados em geral são assegurados o contraditório e ampla defesa, com os meios e recursos a ela inerentes".

$19 \mathrm{Cfe}$. art. $1^{\circ}-\$ 1^{\circ}$ da Lei $9.784 / 99$, dispondo que "os preceitos desta Lei também se aplicam aos órgãos dos Poderes Legislativo e Judiciário da Uniāo, quando no desempenho de função administrativa", e art. $2^{\circ}$ da Lei $9.784 / 99$, dispondo que "a Administração Pública obedecerá, dentre outros, aos princípios da legalidade, finalidade, motivação, razoabilidade, proporcionalidade, moralidade, ampla defesa, contraditório, segurança jurídica, interesse público e eficiência".

20 Cfe. art. 153 da Lei 8.112/90, por analogia, dispondo que "o inquérito administrativo obedecerá ao princípio do contraditório, assegurada ao acusado ampla defesa, com a utilização dos meios e recursos admitidos em direito". 
De tudo isso, a conclusão de que é sábia e jurídica a determinação contida no Manual de Processo Administrativo Disciplinal do Conselho da Justiça Federal, que orienta a instauração e condução de processos disciplinares no âmbito da Justiça Federal, no sentido de que "no processo administrativo disciplinar, dever-se-á observar, rigorosamente, o princípio constitucional da ampla defesa consagrado no art. $5^{\circ}, \mathrm{LV}$, da C.F., para que se assegure uma decisão justa e se evite a argüição do vício de cerceamento de defesa, que contamina o processo de nulidade" 21 .

\section{(c) Ampla defesa na sindicância disciplinar:}

Não obstante a redação do art. $5^{\circ}$-LV da CF/88 seja inequívoca, ainda surgem dúvidas sobre a necessidade de que seja assegurada defesa nas sindicâncias disciplinares, existindo precedentes jurisprudenciais no sentido de que nessa fase é dispensada a defesa do sindicado por se tratar de simples expediente de verificação de irregularidades, equiparável ao inquérito policial em relação à ação penal ${ }^{22}$.

É preciso considerar, entretanto, que a sindicância tem sido desvirtuada e utilizada como instrumento de punição de faltas de menor gravidade, podendo dela então resultar sanção que, embora de menor gravidade, não deixa de constituir penalidade que macula a situação funcional do magistrado ou servidor ${ }^{23}$.

Ora, mesmo antes da Constituição Federal de 1988, a doutrina já defendia que "não só é aplicável [o princípio da ampla defesa] ao processo crime stricto sensu. mas é, também, aplicável a todo e qualquer procedimento em que haja uma acusação e a possibilidade de aplicaçâo de pena, ainda que não se trate da sanção estritamente penal" ${ }^{24}$, sendo então cabível aqui o mesmo raciocínio no sentido de que nessas

21 Cfe. PODER JUDICIÁRIO. Conselho da Justiça Federal. Mamual do Processo Administrativo Disciplinar. Brasília: Conselho da Justiça Federal, 1990, p. 23.

22 Nesse sentido, "I - A sindicância visa, tão-somente, a apuração de irregularidades no serviço, servindo de base, se for o caso, para posterior instauração de processo punitivo. Em razão disso, inexiste violação a inciso LV, do art. $5^{\circ}$, da Lex Legum, haja vista que ainda inexistia o processo administrativo. II - De igual forma, a sindicância dispensa defesa do sindicado no seu procedimento por se tratar de simples expediente de verificação de irregularidade e não de base para punição, equiparável ao inquérito policial em relação à ação penal" (SUPERIOR TRIBUNAL DE JUSTIÇA. ROMS 3.340/PI, rel. min. Pedro Acioli. julgado em 01/03/94. DJU-I 18.04.94. p. 8.528). Em sentido contrário, todavia, "at sindicância (não se confunde com o processo) também enseja defesa, no respectivo limite normativo" (SUPERIOR TRIBUNAL DE JUSTIÇA, ROMS 7.296/BA, rel. Min. Anselmo Santiago, julgado em 24.06.97, DJU-I 29.09.97, p. 48.346).

23 Nesse sentido, é o caso do art. 303 do Regimento Interno do Tribunal Regional Federal da $4^{\mathrm{a}}$ Região. apenas para exemplificar, que dispõe que " as penas disciplinares de advertência e censura serão aplicadas após sindicância, e as de remoção compulsória para os Juízes de Primeira Instância, disponibilidade e aposentadoria compulsória, mediante processo administrativo perante o Plenário precedido de sindicância, de acordo com as disposiçōes deste Regimento" (grifou-se). O mesmo acontece com o art. 145-II da Lei 8.112/90, que estabelece que "da sindicância poderá resultar (...) aplicação de penalidade de advertência ou suspensão de até 30 dias". Ou seja, da sindicância pode resultar aplicação de penalidade disciplinar.

24 Cfe. GRINOVER, Ada Pellegrini. O processo em sua unidade - II. Rio de Janeiro: Forense, 1984, p. 58. 
sindicâncias desvirtuadas, onde existe acusação e de onde pode decorrer aplicação de sanção disciplinar, deve ser oportunizada a defesa ao sindicado, sob pena de nulidade da sanção aplicada ${ }^{25}$.

\section{(d) Meios e recursos inerentes à ampla defesa:}

Para que a defesa possa ser considerada ampla, é preciso que ao acusado seja permitido, pelo menos ${ }^{26}$, o seguinte: (a) ter ciência inicial da acusação, através de citação, e dos demais atos e diligências processuais. através de intimações e irrestrito acesso aos autos; (b) ser assegurada sua audiência, como acusado, mediante interrogatório pessoal; (c) ser assegurado que produza as provas necessárias à demonstração das suas teses de defesa, através dos meios de prova juridicamente permitidos: (d) ser assegurado que acompanhe e interfira na prova, à medida que esta for sendo produzida, através do contraditório e da contraprova: (e) ser assegurado que possa interferir e influenciar no convencimento do julgador, apresentando sua defesa prévia, suas razões finais e sua sustentação oral.

Embora o conteúdo do direito de defesa seja amplo, nesse texto vamos nos deter apenas em algumas situações específicas, que nos parecem merecer atenção em razão

25 Nesse sentido. MEIRELLES, Hely Lopes. Direito Administrativo Brasileiro. $18^{\text {a }}$ edição. São Paulo: Malheiros, 1993, p. 396. É também o entendimento de Ada Pellegrini GRINOVER ( $O$ processo em sua unidade - II. Rio de Janeiro: Forense. 1984, pp. 65-66). apresentado no ano de 1984, muito antes da Constituição Federal de 1988, com argumentação insuperável: " A sindicância suscita um problema prévio de indole conceitual. Porque a sindicância, na verdade, em seu primeiro significado, nada mais é do que um meio de apuração sumária; de apuração de um fato que não deveria, por si só, levar à aplicação de uma pena, abrindo apenas caminho à instauração do processo administrativo. Entendida a sindicância como meio de apuração sumária, observando-se prima facie a similitude da sindicância com o inquérito policial, (...) estaríamos perante mero ato preparatório de um processo administrativo disciplinar. em que se poderia afirmar a desnecessidade de defesa do sindicado, num paralelo exato com o que ocorre no inquérito policial. Acontece, porém, que, conforme permite o nosso Estatuto do Funcionário Público Civil do Estado, é possível, através de mera sindicância, chegar-se à aplicação de uma penalidade. A sindicância. é certo, é instaurada como meio de apuração sumária; mas se. por intermédio dessa apuração sumária, se chegar à verificação da existência de ilícito administrativo e à apuração de sua autoria, a pena administrativa, dentre certos limites. pode ser aplicada ao sindicado por via da própria sindicância. Ora, se isto é possível: se há. portanto. uma transformação da natureza jurídica da sindicância, de meio de apuração sumária que era, em meio de punição e de aplicação de sanção. nesse preciso momento em que a transformação se dá. é igualmente necessário observar o direito de defesa e o contraditório. equiparando o procedimento da sindicância, a partir deste momento, a procedimento do inquérito administrativo. Assim, enquanto a sindicância não leve à imposição de uma sanção, não exige a abservância do direito de defesa e de contraditório. Mas, na medida em que possa ela levar a essa imposiçāo, ainda que de sanção de menor gravidade se trate, impõe-se imediatamente a tutela constitucional compreensiva de todo procedimento 'penal', aplicando-se integralmente o\$15 do art. 153, CF [EC 01/69]" (grifou-se).

26 Nesse sentido, FERREIRA. Sérgio de Andréa. A garantia da ampla defesa no direito adminis. trativo processual disciplinar. Revista de Direito Público. ano V, volume 19. janeiro a março de 1972, p. 64. 
de sua ocorrência freqüente ou das dificuldades que a Administração impõe à defesa dos acusados. Então, a seguir trataremos: (a) dos limites da acusação no processo disciplinar; (b) do direito ao interrogatório do magistrado-acusado; (c) do direito à inquirição das testemunhas arroladas pela defesa; (d) do direito à sustentação oral; (e) do direito de presença do magistrado-acusado e seu procurador na sessão de julgamento: (f) dos efeitos e consequiências do segredo nas sessões de julgamento.

\section{III - Limites à acusação no processo disciplinar}

Se a defesa deve ser ampla, é preciso que o magistrado-acusado saiba do que está sendo acusado, com as circunstâncias da acusação e o nexo de causalidade entre a conduta imputada e a infração aos deveres do seu cargo. A acusação deve ser prévia e precisamente definida, permitindo que o magistrado-acusado saiba do que se defender, saiba quais os fatos que the são imputados, saiba quais as implicações e consequiencias que a acusação pretende tirar desses fatos. Somente assim, com uma acusação precisa e definida, é que a defesa poderá ser amplamente exercida ${ }^{27}$.

Em razão dos tipos abertos que são utilizados para previsão legal das infrações disciplinares atribuídas aos magistrados, é imprescindível que a portaria acusatória seja revestida da suficiente e necessária concretude, para que o magistrado saiba do que efetivamente está sendo acusado e como a autoridade acusadora fez o juízo de subsunção dos fatos ao tipo aberto ${ }^{28}$. Por exemplo, o art. 44 da LOMAN comina a penalidade de censura ao magistrado que incorre em "procedimento incorreto". não definindo exatamente do que se trata. Ora, se a portaria acusatória é vaga e imprecisa sobre o juízo de subsunção, fica inviabilizada a defesa pelo magistrado-acusado, que não tem como controlar e contraditar a imputação de procedimento incorreto que Ihe é feita pela peça acusatória ${ }^{29}$.

27 Nesse sentido, "a Portaria é o instrumento idôneo de que se utiliza a autoridade administrativa para formalizar o processo disciplinar. (...) É pela Portaria que se delimita o alcance das acusações, devendo a Comissão ater-se aos fatos ali descritos, só podendo alcançar outros fatos quando vinculados com as irregularidades delineadas na Portaria Instauradora" (PODER JUDICIÁRIO. Conselho da Justiça Federal. Manual do Processo Administrativo Disciplinar. Brasília: Conselho da Justiça Federal, 1990, p. 17).

28 Cfe. GRINOVER, Ada Pellegrini. O processo em sua unidade - II. Rio de Janeiro: Forense. 1984. p. 65.

29 Aliás, o tipo disciplinar "procedimento incorreto". previsto no art. 44 da LOMAN. é inconstitucional pela ausência de legalidade estrita e pela ausência de impessoalidade. A aplicação de sanção disciplinar é ato administrativo, agindo inconstitucionalmente o administrador que aplica penalidade sem observar a estrita legalidade e a impessoalidade (art. 37, caput da CF/88). No âmbito disciplinar, um tipo não pode ser aberto. Sob pena de se tornar produto de puro arbítrio ou capricho do administrador, a tipicidade da conduta não pode depender de valoração personalíssima (impessoalidade). nem pode aceitar qualquer conteúdo (legalidade estrita, e não apenas mera legalidade). Assim, onde não existe um padrão objetivo de verificação da conduta (que permita impessoalmente diferenciar o procedimento correto do incorreto), o preenchimento do conteúdo da figura típica fica dependendo do exclusivo arbítrio do administrador, violando os princípios do art. 37. capu da 
Além disso, a abertura e vaguidade desse tipo disciplinar acaba permitindo que a acusação seja preenchida com critérios subjetivos ou personalíssimos, em flagrante descumprimento aos princípios de estrita legalidade e impessoalidade, previstos no art. 37. caput da $\mathrm{CF} / 88$, o que realça então a necessidade de que a portaria acusatória seja clara e precisa, e que a acusação seja previamente formulada de forma completa e defensável.

Por fim, disso decorre que a acusação não pode ser livremente aditada no curso do procedimento disciplinar, tão-somente para que sejam supridas as falhas da peça acusatória inicial ${ }^{30}$. As emendas e aditamentos à acusação inicial, feitas no curso do procedimento, precisam se submeter ao devido processo e ao contraditório, assegurando-se sempre a prévia manifestação da defesa e possibilidade do magistrado-acusado produzir novas provas para contrapor-se às acusações emendadas ou aditadas, sob pena de vício do procedimento por cerceamento do direito de ampla defesa.

\section{IV - Interrogatório do acusado}

Como qualquer outro acusado, também o magistrado-acusado em processo disciplinar tem direito a ser interrogado pessoalmente pela autoridade processante, se assim o desejar e requerer. Da mesma forma que a autoridade processante pode determinar esse interrogatório, o magistrado-acusado pode também pretender prestá-lo espontaneamente, quando então deverá ser interrogado e ouvido (autodefesa), sob pena de cerceamento do direito de defesa ${ }^{3 !}$.

O interrogatório não se confunde nem pode ser substituído pela defesa técnica, que o magistrado-acusado apresenta por escrito, seja em nome próprio, seja acompanhado por procurador. Efetivamente, a defesa técnica e a autodefesa são vertentes diversas e complementares da mesma garantia, conexa à exigência fundamental do

CF/88 e sendo inconstitucional (LEAL JÚNIOR, Cândido Alfredo Silva. Os Juizes, a Corregedoria e as Correiçōes Ordinárias: Considerações sobre um 'Manual de Correições'. Direito Federal: Revista da Associação de Juízes Federais do Brasil. Brasília, ano 21, vol. 71, julho a setembro de 2002, pp. 99-120).

30 Nesse sentido. "a narração deficiente ou omissa, que impeça ou dificulte o exercício da defesa, é causa de nulidade absoluta. não podendo ser sanada porque infringe os princípios constitucionais" (GRINOVER, Ada Pellegrini; FERNANDES, Antonio Scarance; e GOMES FILHO, Antonio Magalhães. As nulidades no processo penal. Sĩo Paulo: Malheiros, 1992, p. 78).

31 Nesse sentido, "a par da autodefesa do acusado, consubstanciada em sua atuação pessoal no processo penal, especialmente no ato de interrogatório, e que deve ser espontânea, imprescindível torna-se a efetivação de defesa técnica, normalmente, ou seja, salvo situações excepcionais, a cargo de profissional habilitado, com capacidade postulatória" (TUCCI, Rogério Lauria, e TUCCI, José Rogério Cruz e. Constituição de 1988 e Processo. São Paulo: Saraiva, 1989, p. 63). Além disso, aplicado analogicamente ao processo disciplinar. diz-se que "no processo penal, entendem-se indispensáveis quer a defesa técnica, exercida por advogado, quer a autodefesa, com a possibilidade dada ao acusado de ser interrogado e de presenciar todos os atos instrutórios" (CINTRA. Antonio Carlos de Araújo: GRINOVER, Ada Pellegrini, e DINAMARCO. Cândido Rangel. Teoria Geral do Processo. $7^{2}$ edição. São Paulo: Revista dos Tribunais. 1990, p. 56). 
contraditório $^{32}$. Quando a autoridade processante impede o interrogatório pessoal do magistrado-acusado, está mutilando suas possibilidades de colaborar com sua defesa na apresentação de considerações em seu favor, negando então ao acusado seu direito à defesa ampla. A defesa fica limitada, sendo cerceada a real e concreta possibilidade de produzir provas e defesas por intermédio de sua audiência pessoal pela autoridade processante.

O interrogatório pessoal (a autodefesa) é importante e essencial à defesa do acusado, porque permite à autoridade processante e julgadora manter contato imediato e direto com a pessoa contra a qual se pede aplicação da penalidade disciplinar. Esse contato é necessário porque "propicia ao julgador o conhecimento da personalidade do acusado e lhe permite, também, ouvindo-o, cientificar-se dos motivos e circunstâncias do crime, elementos valiosos para a dosagem da pena. E o legislador quer que o julgador ouça o acusado não só para que se tenha certeza de que ele é. realmente, a pessoa contra quem se propôs a ação penal. como também para que o Juiz conheça sua personalidade, saiba em que circunstâncias ocorreu a infração porque ninguém melhor que o acusado para sabê-lo - e quais os seus motivos determinantes. Por outro lado, durante o interrogatório, colhe o Juiz elementos para o seu convencimento. É natural, pois, a necessidade desse contato entre julgador e imputado" 33 .

Ou seja, o interrogatório não é apenas fonte de provas, mas também meio de defesa de qualquer acusado, inclusive do magistrado-acusado. Por intermédio dele, pode oralmente contestar a acusação e expor sua própria versão dos fatos e suas circunstâncias na presença do julgador, fornecendo assim valiosos subsídios para o julgamento do processo disciplinar.

O interrogatório requerido pelo magistrado-acusado não pode ser dispensado pela autoridade processante ainda quando a defesa técnica tenha sido feita pelas mãos do próprio acusado, que possui capacidade postulatória para tanto. Uma petição escrita (defesa técnica) não dispensa nem se confunde com o interrogatório oral (autodefesa). O interrogatório é pessoal e não pode ser escrito. A autodefesa, da qual o direito de presença e de audiência decorrem, envolve a presença do acusado perante o julgador. A linguagem escrita não intermedeia o contato julgador-acusado. No interrogatório, as perguntas são feitas pelo julgador diretamente ao acusado, o acusado as responde diretamente ao julgador, e só então este as reduz a termo escrito. O contato entre ambos é imediato, atual, real, verbal, visual. Vêem-se os olhos, escutam-se as vozes. O mais perigoso dos bandidos e o mais humilde dos acusados

32 Cfe. GRINOVER. Ada Pellegrini. Novas Tendências do Direito Processual. Rio de Janeiro: Forense Universitária, 1990, pp. 9-10. Também GRINOVER, Ada Pellegrini: FERNANDES, Antonio Scarance; e GOMES FILHO, Antonio Magalhães. As nulidades no processo penal. São Paulo: Malheiros, 1992, p. 64.

33 Cfe. TOURINHO FILHO, Fernando da Costa. Processo Penal, $3^{\circ}$ volume. $13^{a}$ edição. São Paulo: Saraiva, 1992, p. 240. Embora referindo-se ao processo penal, tais considerações são integralmente cabíveis quanto ao processo disciplinar, dada a semelhança e natureza sancionadora de ambos os procedimentos, conforme já examinamos nesse texto. 
têm direito de serem ouvidos pessoalmente pelo julgador, não havendo razão para que esse direito seja negado ao magistrado-acusado tão-somente por ser magistrado ou por estar elaborando suas próprias petições de defesa. Petições técnicas e papéis escritos não substituem a presença do acusado diante do julgador. Com pouco talento e algum conhecimento, um papel escrito mascara a verdade. Mas o interrogatório pessoal dificilmente deixa dúvidas sobre a sinceridade das declarações e intenções.

Por isso, o Manual do Processo Administrativo Disciplinar do Conselho da Justiça Federal estabelece que a ampla defesa funda-se, entre outros, no direito de "prestar depoimento sobre as imputações que lhes são feitas e sobre os fatos que a geraram" 3.4 . E o art. 159, caput da Lei 8.112/90, que disciplina o processo administrativo disciplinar relativo a servidores públicos federais e serve como fonte subsidiária para o processo disciplinar instaurado contra magistrados, nas lacunas da Lei Orgânica da Magistratura, estabelece que "concluída a inquirição das testemunhas, a comissão promoverá o interrogatório do acusado, observados os procedimentos previstos nos arts. 157 e $158^{\prime \prime}$. Ou seja, antes do julgamento e do encerramento das fases postulatória e instrutória, a autoridade processante deve necessariamente interrogar pessoalmente o magistrado-acusado, se esse assim o requereu, sob pena de cerceamento de defesa e nulidade absoluta, à semelhança do que ocorre no processo penal $^{35}$.

\section{$V$ - Inquirição de testemunhas de defesa}

Também integra o direito à ampla defesa, complementando-o, o direito à pro$\mathrm{va}^{36}$, que é visto como "a faculdade reconhecida à parte de fazer encartar nos autos do processo todos os elementos de convicção de que dispõe, com a finalidade de demonstrar a verdade dos fatos que embasam suas alegações" 37 .

Por ser evidente, pouco precisa ser dito sobre a importância do direito à prova para o pleno exercício da ampla defesa do magistrado-acusado. A atividade probatória é momento central do processo, que tem ligações estreitas com as fases postulatória e julgadora, porque "o concreto exercício da ação e da defesa fica essencialmente subordinado à efetiva possibilidade de se representar ao juiz a realidade do fato posto como fundamento das pretensões das partes, ou seja, destas poderem

34 Cfe. PODER JUDICIÁRIO. Conselho da Justiça Federal. Manual do Processo Administrativo Disciplinar. Brasília: Conselho da Justiça Federal, 1990, p. 23.

35 Cfe. GRINOVER, Ada Pellegrini; FERNANDES, Antonio Scarance; e GOMES FILHO, Antonio Magalhães. As nulidades no Processo Penal. São Paulo: Malheiros, 1992, pp. 70-71.

36 Nesse sentido, "a ampla defesa funda-se principalmente no direito de: (...) d) arrolar e inquirir, reinquirir e contraditar testemunhas e requerer acareações" (PODER JUDICIÁRIO. Conselho da Justiça Federal. Manual do Processo Administrativo Disciplinar. Brasília: Conselho da Justiça Federal, 1990, p. 23).

37 Cfe. TUCCI, Rogério Lauria, e TUCCI, José Rogério Cruz e. Constituição de 1988 e Processo. São Paulo: Saraiva, 1989, p. 68. 
servir-se das provas" ${ }^{38}$. Se não foi assegurado ao magistrado-acusado a produção das provas que eram necessárias à sua defesa, esta não foi ampla e então foi cerceada, havendo nulidade do processo disciplinar e de eventual sanção que lhe seja decorrente.

Inserida na dilação probatória, está a faculdade do magistrado-acusado arrolar e inquirir testemunhas de defesa para a prova dos fatos e circunstâncias da sua defesa, bem como para contrapor-se ao contido na peça acusatória inicial. Embora a Lei Orgânica da Magistratura não traga previsão específica quanto a isso, essa faculdade decorre do direito de ampla defesa, do contraditório e da aplicação analógica das disposições pertinentes ao regramento do processo disciplinar dos servidores públi$\cos ^{39}$ e do próprio processo penal, mencionando o Manual do Processo Administrativo Disciplinar do Conselho da Justiça Federal que "na inquirição das testemunhas observar-se-á, no que couber, o disposto no Código de Processo Penal" e que "o acusado deve ser notificado da oitiva das testemunhas, podendo assistir aos depoimentos, reperguntando através do Presidente da Comissão" ${ }^{40}$, o que também é aplicável quando se trata de processo disciplinar instaurado contra magistrado.

Obviamente, as provas manifestamente desnecessárias, flagrantemente inúteis ou notadamente protelatórias podem ser indeferidas pela autoridade processante, através de decisão fundamentada ${ }^{41}$. Mas é preciso que a autoridade processante não se deixe confundir pela peculiar posição que detém no processo disciplinar, de estrutura inquisitória, em que se confundem as figuras de acusador e julgador. No instante em que o acusador é o próprio diretor e julgador do processo disciplinar, tendo ele elaborado a portaria acusatória e instaurado o processo disciplinar, pode ser que se veja tentado a considerar os pontos da acusação suficientemente provados e considerar desnecessárias ou protelatórias as provas da defesa, mormente as testemunhas com que o magistrado-acusado pretende provar sua versão dos fatos e as circunstâncias de sua conduta.

Nessas situações em que a condenação está definida antes mesmo do processo (prejulgamento), chegando a autoridade processante ao ponto de indeferir de plano todas as diligências da defesa por (pré-)julgá-las desnecessárias ou protelatórias, está-se diante de violação aos princípios que devem reger a atuação administrativa, tal como previsto no art. 37, caput da CF/88. Essa conduta preconceituosa da autoridade processante torna inútil o próprio processo disciplinar. Afinal, por que seria necessário o processo disciplinar, com suas fases e formalismo, se a acusação

38 Cfe. GRINOVER, Ada Pellegrini; FERNANDES, Antonio Scarance; e GOMES FILHO, Antonio Magalhães. As nulidades no processo penal. São Paulo: Malheiros, 1992, pp. 98-99.

39 Cfe. arts. 156-159 da Lei 8.112/90, especialmente o disposto no seu art. 156. capur: "é assegurado ao servidor o direito de acompanhar o processo pessoalmente ou por intermédio de procurador, arrolar e reinquirir testemunhas, produzir provas e contraprovas e formular quesitos, quando se tratar de prova pericial" (grifou-se).

40 Cfe. PODER JUDICIÁRIO. Conselho da Justiça Federal. Manual do Processo Administrativo Disciplinar. Brasília: Conselho da Justiça Federal, 1990, pp. 23-24.

41 Cfe. TUCCI, Rogério Lauria, e TUCCI, José Rogério Cruz e. Constituição de 1988 e Processo. São Paulo: Saraiva, 1989, p. 69 
já é considerada de plano procedente pela autoridade processante, que sequer se digna ouvir as razões da defesa do acusado? Indeferindo as provas de defesa, a autoridade processante cerceia a ampla defesa do acusado, faz preconceituoso prejulgamento dos fatos e impede que se tenha um processo disciplinar justo e legítimo, viciando eventual sanção disciplinar que venha a ser aplicada, o que então poderá ser controlado pela via jurisdicional apropriada. Mesmo que tenha natureza inquisitória, o processo disciplinar se submete ao princípio do contraditório por força do art. $5^{\circ}-\mathrm{LV}$ da $\mathrm{CF} / 88$ e aos princípios do art. 37 . caput da $\mathrm{CF} / 88^{42}$, que impedem que a pessoalidade ou idéias preconcebidas da autoridade processante possam esvaziar os direitos constitucionais do magistrado-acusado.

É de se mencionar que se existir alguma dúvida da autoridade processante quanto ao conteúdo ou necessidade da inquirição das testemunhas da defesa, poderá facultar ao acusado que especifique as perguntas que irá formular às testemunhas e indique os fatos que pretende provar com sua inquirição, permitindo que assim possa aferir a pertinência e necessidade da inquirição. $O$ que não se pode aceitar é que seja simplesmente cerceada de plano a produção de todas as provas do acusado, utilizando-se o processo disciplinar tão-somente como instrumento para se tentar legitimar a aplicação de uma sanção disciplinar decidida de forma autoritária e preconceituosa, a despeito da defesa apresentada e antes mesmo da instrução probatória, que se cerceia.

Além disso, outra questão que pode suscitar discussão é a possibilidade da inquirição de testemunha ser substituída pela apresentação de declarações escritas da pessoa que se pretende ouvir, previamente elaboradas sem que o magistrado-acusado pudesse formular perguntas e reperguntas à testemunha, ou submetê-la ao crivo do contraditório. Os princípios da imediatidade e da concentração da produção da prova impedem que a inquirição oral e presencial de testemunhas seja substituída por artificios, tendentes a dificultar a ampla defesa ou impedir o contraditório ${ }^{43}$.

Também tem o magistrado-acusado direito a arrolar e inquirir aquela pessoa de quem partiu a representação que deu origem ao processo disciplinar. Realmente, é direito do acusado inquirir o representante para esclarecer fatos e circunstâncias que não tenham ficado suficientemente esclarecidos na representação, de onde se originou a portaria acusatória. É seu direito inquiri-lo como testemunha, para contraditá-lo e assim demonstrar o desacerto da representação, sendo uma das formas

42 Nesse sentido, examinando o disposto na Lei 8.112/90, o Supremo Tribunal Federal já decidiu que o contraditório deve ser observado no processo disciplinar, afirmando que " pela Lei atual. o inquérito administrativo tem de obedecer ao princípio do contraditório (que é assegurado ao acusado pelo seu artigo 153) também na fase instrutória, como resulta inequivocamente dos artigos 151, II, 156 e 159" (SUPREMO TRIBUNAL FEDERAL. MS 21.721-9/RJ, rel. Min. Moreira Alves, julgado em 13.04.94, DJU-I 10.06.94).

43 Nesse sentido, o art. 336 do CPC dispõe: "salvo disposição especial em contrário, as provas devem ser produzidas em audiência". Assim, devem ser produzidas em audiência as provas de natureza oral, isto é, as por testemunhas, por depoimento pessoal e consistentes em esclarecimentos do perito e dos assistentes técnicos (SANTOS, Moacyr Amaral. Comentários ao Código de Processo Civil. $7^{a}$ edição. Rio de Janeiro: Forense, 1994, p. 45). 
eficazes de que esse resultado seja alcançado é submetendo o representante à acareação e imediação que são próprias da prova testemunhal, quando então serão colhidos preciosos subsídios para o posterior julgamento do processo disciplinar.

Essa inquirição do representante, não obstante aquilo que tenha apresentado e encaminhado à autoridade disciplinar na representação para instauração do processo, se justifica porque: (a) o representante pode conhecer fatos que não fez constar na representação, mas que seriam relevantes para a defesa do magistrado-acusado; (b) pode ter havido desvio de finalidade ou abuso de poder na representação disciplinar, o que então poderá ser identificado com a inquirição e acareação do representante perante a autoridade processante; (c) a defesa precisa ter tratamento igual àquele dispensado à acusação, e se o representante pode apresentar unilateralmente sua versão dos fatos (através da representação), é preciso que essas declarações unilaterais sejam submetidas ao crivo do contraditório, sob o compromisso legal de dizer a verdade, assegurando ao acusado direito de formular perguntas e reperguntas àquele que se disse ofendido, produzindo-se então prova relevante para sua absolvição. Do contrário, quebra-se o direito de contraditório assegurado a todo acusado (art. $5^{\circ}$ - $\mathrm{LV}$ da $\mathrm{CF} / 88$ ), porque se a palavra e as declarações do representante valem como provas para a acusação, então a defesa tem inafastável direito de formular perguntas e reperguntas para contraditar aquelas palavras e demonstrar sua improcedência.

\section{$V I$ - Direito à sustentação oral}

Também integra o direito de ampla defesa do magistrado-acusado a possibilidade de, pessoalmente ou por intermédio de procurador, fazer-se presente à sessão de julgamento e nela sustentar oralmente suas razões de defesa perante todos os julgadores.

Sendo o julgamento do processo disciplinar realizado por todos os membros do Tribunal $^{\text {t4 }}$, é preciso que seja assegurado ao magistrado-acusado que apresente perante eles suas razões de defesa. não apenas por escrito (razões finais). mas também de forma oral (sustentação oral), imediatamente antes do julgamento e do voto dos membros do Tribunal.

Havendo interesse do magistrado-acusado na realização de sustentação oral, ele tem direito subjetivo à mesma, sob pena de vício e nulidade do julgamento, porque os membros do Tribunal estão obrigados a ouvir a defesa técnica do acusado, em todas as suas formas. $\mathrm{O}$ interrogatório do acusado é o momento por excelência de

$44 \mathrm{O}$ art. 93-X da CF/88 exige que as decisões disciplinares sejam tomadas pelo voto da maioria absoluta dos membros dos Tribunais, evidenciando assim que a sessão de julgamento não pode envolver apenas órgão fracionário do Tribunal, exigindo o quorum qualificado do Plenário do respectivo Tribunal, sob pena de nulidade. Nesse sentido, "as penas de advertência e de censura são aplicáveis aos juizes de $1^{\circ}$ grau, pelo Tribunal, pelo voto da maioria absoluta de seus membros", sendo inconstitucional disposição de regimento interno de Tribunal que atribua esse julgamento a órgão fracionário (SUPREMO TRIBUNAL FEDERAL, ADIn 2.580-5/CE, rel. Min. Carlos Velloso, julgado em 26.09.02, DJU-I 21.02.03, grifou-se). 
sua autodefesa, enquanto a sustentação oral depois do encerramento da instrução, privilegiando a oralidade e a imediatidade entre defesa e julgadores, é o momento por excelência de sua defesa técnica, em que a matéria fática pode ser apreciada e as teses jurídicas evidenciadas.

A sustentação oral não pode ser substituída pelo interrogatório pessoal do acusado ou por memoriais escritos de razões finais, porque são momentos distintos da defesa, com finalidades distintas, que não se confundem. Sobre o interrogatório, bastante já foi dito nesse texto, nada sendo preciso acrescentar senão destacar o fato de que não se confunde nem substitui a sustentação oral. Sobre os memoriais escritos de razões finais, também não se confundem com a sustentação oral, porque não há garantia de que os julgadores lerão as petições escritas e as teses apresentadas pela defesa, sendo a sustentação oral o momento em que isso é garantido, porque os julgadores somente não vão escutar se taparem seus ouvidos (o que será por todos facilmente percebido, constrangendo o julgador preconceituoso), obrigando-se então a conhecerem os motivos e as versões da defesa, os quais necessariamente deverão ser considerados no voto absolutório ou condenatório que proferirem.

O direito à sustentação oral não está previsto na Lei Orgânica da Magistratura, mas isso não significa que possa ser dispensada pelos Tribunais no julgamento de processos disciplinares. Dada a semelhança entre o processo disciplinar e o processo penal, quando estes tramitam e são julgados por órgãos colegiados, aplicam-se analogicamente as regras pertinentes aos processos da competência originária dos Tribunais $^{45}$, destacando-se aqui o que prevê o art. 12 da Lei 8.038/90, que regula esses julgamentos perante o Superior Tribunal de Justiça e o Supremo Tribunal

45 Nesse sentido, não tratando especificamente da sustentação oral, mas permitindo a conclusão defendida no texto, cabe citar o acórdão do RMS 334-RJ, do Superior Tribunal de Justiça, onde constou voto-vista do Min. Hélio Mosimann, nesses termos: "O direito de defesa é direito público subjetivo, cuja origem remonta aos tempos antigos. É o que diz Sahid MALUF, no seu Direito Constitucional, $3^{\text {a }}$ edição, pág. 417, trazendo a lição de João BARBALHO: 'A lei não quer a perdição daqueles que a Justiça processa; quer só que bem se apure a verdade da acusação e, portanto, todos os meios e expedientes de defesa que não impeçam o descobrimento dela (a verdade) devem ser permitidos aos acusados. A lei os deve facultar com largueza, regularizando-os para não tornar tumultuário o processo. Com a ampla defesa são incompatíveis e, portanto, inteiramente inadmissíveis, os processos secretos, inquisitoriais', entre outros. Alega-se que a presença do acusado e advogado não está expressamente prevista na Lei Orgânica, disciplinadora do processo, que seria incabível defesa oral e que cópias das razões finais foram distribuídas com necessária antecedência. Por isso, o requerimento para estarem ali nos minutos que antecediam à deliberação secreta (fls. 236/237) fora indeferido. Todavia, 'tudo o que for razoavelmente necessário é admissível, ainda que a medida não esteja expressamente prevista na lei processual. O Juiz só pode indeferir os requerimentos de defesa quando sejam abusivos, protelatórios, impertinentes ou evidentemente desnecessários' (Direito Constitucional, Sahid MALUF, pág. 416). Nem é o caso e nem a lei proíbe, sob outro ângulo, as presenças previamente solicitadas (RI do STJ admite, art. 228 e Lei 8.038/90)" (SUPERIOR TRIBUNAL DE JUSTIÇA, RMS 334-RJ, voto-vista do Min. Hélio Mosimann). Como se vê, nesse voto há menção à aplicação analógica do disposto na Lei $8.038 / 90$ ao processo disciplinar, evidenciando-se assim a semelhança entre as duas pretensões punitivas (disciplinar e penal) e o cabimento da aproximação dos ritos pertinentes, naquilo que for cabível. 
Federal: "Finda a instrução, o Tribunal procederá ao julgamento, na forma determinada pelo regimento interno, observando-se o seguinte: I - a acusação e a defesa terão, sucessivamente, nessa ordem, prazo de uma hora para sustentação oral, assegurado ao assistente um quarto do tempo da acusação; II - encerrados os debates, o Tribunal passará a proferir o julgamento, podendo o Presidente limitar a presença no recinto às partes e seus advogados, ou somente a estes, se o interesse público o exigir" (grifou-se).

Ora, dada a natureza das pretensões punitivas envolvidas e descontada a natureza inquisitorial do processo disciplinar, não há como deixar de reconhecer ao magistrado-acusado o direito de sustentar oralmente suas razões de defesa durante a sessão de julgamento e antes da prolação dos votos dos membros do Tribunal ${ }^{46}$.

Por fim, cabe dizer que a sustação oral é essencial para que seja assegurada a ampla defesa ao magistrado-acusado, porque é nesse momento em que ele pode apresentar sua versão final dos fatos, com a certeza de que os julgadores não deixarão de ouvi-lo e necessariamente estarão cientes das suas teses de defesa e, principalmente, daqueles fatos tratados no processo disciplinar e respectiva prova.

Além de assegurar a oralidade e a imediação entre defesa e julgamento, também a sustentação oral desempenha relevante papel preservando a imparcialidade dos julgadores e impedindo que se escusem na cômoda desculpa de ignorância dos fatos, limitando-se a acompanhar o voto-relator. Ora, o magistrado-acusado tem direito de ser ouvido por seus julgadores, e não apenas de ser lido nas suas petições escritas. Essa leitura depende da visão (sentido ativo), que por sua vez depende da direção que o julgador dá aos seus olhos. O que ele não quer ver, ele facilmente não vê. Basta desviar o olhar. Mas a audição, de que se serve a sustentação oral, é sentido passivo, que não depende da vontade de alguém que não queira escutar. Não adianta não-querer escutar (ou querer não-escutar), porque obrigatoriamente se escuta o que está sendo dito na tribuna. Ao contrário de outros animais, que podem comandar suas orelhas na direção que desejam, os seres humanos têm orelhas fixas, imóveis, que não podem ser direcionadas segundo a vontade de quem escuta. Logo, a audição não depende da vontade de quem escuta e se o julgador pretendesse manter-se ignorante quanto às razões de defesa, teria que fechar os ouvidos com as mãos. Mas então seria facilmente desmascarado pelo acusado, que perceberia a manobra e ali identificaria a nulidade do voto daquele julgador. Ao contrário das petições escritas, que o julgador pode impunemente deixar de ler, não é fácil deixar de ouvir a

46 Nesse sentido, por exemplo, o Regimento Interno do Tribunal Regional Federal da $4^{\mathbf{a}}$ Região contém norma semelhante àquela do art. 12 da Lei 8.038/90, disciplinando o processo das ações penais originárias, sendo assegurada a sustentação oral para apresentação das razões de defesa, nesses termos: "Art. 195 [do Regimento Interno do TRF4ª]. Finda a instrução, a Seção procederá ao julgamento, observando-se o seguinte: (...) V - encerradas as inquirições e efetuada as diligências que a Seção houver determinado, o Presidente dará a palavra à acusação e à defesa, que terāo, sucessivamente, nessa ordem, prazo de uma hora para a sustentação oral, assegurado ao assistente $1 / 4$ do tempo da acusação; VI — após os debates, a Seção passará a proferir o julgamento" (grifou-se). 
sustentação oral sem constrangimento ao julgador relapso, o que o obriga prestar atenção às razões de defesa e assim diminui os riscos de julgamento parcial ou viciado por preconceitos do julgador.

Então, um acusado tem direito não apenas de escrever suas petições e apresentá-las aos olhos do julgador, que poderá não as ler, mas também tem direito a pronunciar suas palavras, sustentando oralmente suas razões, que então obrigatoriamente serão ouvidas e escutadas por aqueles que estão obrigatoriamente presentes na sessão de julgamento. Isso é suficiente para mostrar a distinção substancial entre razões escritas e sustentação oral, e a finalidade de cada uma delas. E, por serem distintas e relevantes, cada uma deles é imprescindível para que se tenha respeitado o amplo direito de defesa de todo acusado, sob pena de nulidade.

\section{VII - Direito de presença na sessão de julgamento}

O magistrado-acusado tem direito a estar presente na sessão de julgamento, acompanhando todas as discussões e votos. Efetivamente, como já foi dito pelo Superior Tribunal de Justiça, "se a defesa de qualquer acusado deve ser ampla mesmo porque se assim não fosse não seria completa - nenhuma razão para proibir a presença dos maiores interessados no julgamento, a parte e seu advogado" 47 . O art. $5^{\circ}$ - LV da CF/88 assegura a ampla defesa e o art. 93-X da CF/88 estabelece que todas as decisões dos Tribunais serão motivadas, de onde se conclui que o magistrado-acusado e seu procurador têm inarredável direito de assistirem e se fazerem presentes em todos os momentos da sessão de julgamento, exercendo a físcalização e o controle do devido processo e da lisura do julgamento ${ }^{48}$.

Se o magistrado-acusado e seu procurador forem impedidos de estar presentes em todos os atos e momentos da sessão de julgamento, então teremos nulidade absoluta pelo cerceamento da ampla defesa, sendo evidente o prejuízo e desnecessária sua demonstração para que a nulidade seja reconhecida e vicie eventual aplicação de penalidade disciplinar que ali tenha sido decidida. $O$ magistrado-acusado tem direito inarredável de acompanhar toda a sessão de julgamento, inclusive depois de proferida sua sustentação oral, porque é essa presença que permite fiscalizar se os votos foram secretos, se houve alguma irregularidade, se votou quem nâo poderia fazê-lo, se quem estava impedido ou era suspeito tomou parte nas discussões, etc.

47 Cfe. SUPERIOR TRIBUNAL DE JUSTIÇA, ROMS 1.104/RJ, $2^{\text {a }}$ Turma, Rel. p/ o acórdão Min. Hélio Mosimann, julgado em 16.12.96, DJU-I 20.10.97, p. 53.019.

48 Nesse sentido, falando sobre a reserva ná aplicação e tramitação do processo disciplinar, diz-se que "o sigilo e a reserva não se aplicam ao juiz e a seu procurador. Quando, por exemplo, o art. 27. $\$ 6^{\circ}$, da LOMAN estabelece o julgamento em sessão secreta, não está a excluir a presença do juiz e de seu procurador, sob pena de evidente maltrato ao postulado constitucional do contraditório e ampla defesa, inafastáveis também quanto ao procedimento administrativo (art. $5^{\circ}, \mathrm{LV}$, da CF/88)" (GODOY, Cláudio Luiz Bueno de. Responsabilidade Disciplinar dos Juizes. Controle Interno da Magistratura. In: FREITAS, Vladimir Passos de (organizador). Corregedorias do Poder Judiciário. São Paulo: Revista dos Tribunais, 2003, pp. 99-100). 
A questão, aliás, não é nova na jurisprudência do Superior Tribunal de Justiça, que entende ser incompatível com as garantias da ampla defesa e da motivação das decisões que seja negada a participação do acusado e seu procurador na sessão de instauração ou julgamento do processo disciplinar ${ }^{49}$, decretando-se então a nulidade da punição disciplinar imposta naquela sessão.

\section{VIII - Nulidade do processo disciplinar}

A previsão legal de um "devido processo" (art. 50-LIV da CF/88) e as finalidades do processo administrativo-disciplinar contra magistrado (art. 96-I-b da CF/88) fazem necessária a observância estrita das formalidades legais do rito procedimental pertinente. É a observância do devido processo disciplinar que tem condições de permitir a aplicação válida de punição disciplinar, porque a forma do procedimento tem essa finalidade de instrumentalizar a correta e justa aplicação da lei ${ }^{50}$.

49 Nesse sentido, " 1 - Configura cerceamento ao direito de defesa assegurado a toda pessoa, proibir a presença do magistrado ou do seu advogado no recinto da sessão. no momento da votação. ainda que tenham sido apresentadas as alegaçōes tinais. em processo onde é aplicada a pena de disponibilidade. 2- Os julgamentos do Poder Judiciário são públicos e fundamentadas todas as decisões. sob pena de nulidade, sem vez a votação secreta. 3- Ao acusado ou ao seu defensor. segundo o interesse público o reclamar, não se pode negar o direito de acompanhar todo o processo. incluída a votação. quando poderá - exemplo - fiscalizar se os votos foram secretos, se ocorreu alguma irregularidade, se votou quem não poderia fazê-lo. Enfïm, defender-se não como um curioso, mas como interessado, visando a que o julgamento seja imparcial e sem vícios, uma vez que a decisão lhe interessa diretamente" (SUPERIOR TRIBUNAL DE JUSTIÇA, RMS 1932-9/PR, 5 Turma, Rel. Min. Costa Lima, julgado em 10.03.93. DJU-I 12.04.93). Também: “Verificando-se que não foi permitida a participação do acusado e do seu defensor na sessão na qual foi instaurado procedimento administrativo, é flagrante a violação ao princípio da ampla defesa. Prática que não se coaduna com as garantias estabelecidas na Lex Máxima (art. 93, inciso IX)" (SUPERIOR TRIBUNAL DE JUSTIÇA, ROMS 10.731/BA. 5" Turma. Rel. Min. Felix Fischer, julgado em 01.06.99, DJU-I 16.08.99. p. 88). Também: "Alegação (de nulidade da punição) acolhida tão-somente no que concerne ao cerceamento de defesa. caracterizado pela realização do julgamento sem a presença dos acusados e seus advogados, os quais ficaram impossibilitados de apresentar defesa oral: de. eventualmente, arguir o impedimento de desembargadores que dele participaram: e de certificar-se da observância do quorım constitucional para composição e deliberação. Segurança parcialmente concedida, para o fim de anular o processo, a partir do julgamento" (SUPERIOR TRIBUNAL DE JUSTIÇA, RMS 417-RJ, rel. min. Ilmar Galvão. julgado em 05.06.9l, DJU-I 23/09/91).

50 Nesse sentido, " se de um lado o processo não será um verdadeiro processo enquanto não proteger as partes, no sentido de lhes dar a oportunidade de sustentarem suas razões, de produzirem sua defesa, de apresentarem suas provas, de influírem sobre a formaçāo do convencimento do juiz. de outro lado a resposta jurisdicional, por sua vez. não será legítima. nem será resposta jurisdicional, enquanto não representar o coroamento de um processo que obedeça a essas garantias. Quer quando se considere o processo sob o ponto de vista da ação, movida pelo autor. e da defesa, oposta pelo réu: quer quando se o considere do ponto de vista do Estado, como jurisdição (atividade e exercício de função), o devido processo legal tutela. de um lado, o direito público subjetivo do autor e do réu, e, de outro lado, a própria jurisdição, legitimando-a" (GRINOVER, Ada Pellegrini. O processo em sua unidade - II. Rio de Janeiro: Forense, 1984, pp. 60-61). 
Aliás, se não fosse preciso observar as formalidades e requisitos legais, não seria preciso processo disciplinar para aplicação da sanção. A autoridade administrativa então aplicaria de plano a sanção disciplinar, sem qualquer outro procedimento que o próprio ato sancionador ${ }^{51}$. Mas não é assim. É preciso que o procedimento disciplinar seja seguido (devido processo), porque é isso que permite que os princípios do art. 37 , caput da $\mathrm{CF} / 88$ sejam observados ou, pelo menos, que permite que a eventual inobservância desses princípios pela conduta administrativa disciplinar seja identificada e controlada pelas vias próprias.

Surge então a categoria de nulidade do processo disciplinar, que é conceituada como "o vício de forma que, provocando prejuízo em detrimento da verdade substancial dos fatos imputados ao servidor acusado, contamina a validade do ato e do respectivo processo" 52 .

Assim, tanto o indeferimento de provas relevantes requeridas pela defesa, quanto a inobservância de regras procedimentais, trazendo prejuízo ao direito de ampla defesa do magistrado-acusado, importam a nulidade do processo disciplinar e sua inconsistência jurídica para aplicação de eventual penalidade disciplinar ao magistrado-acusado ${ }^{53}$

O prejuízo, que autoriza o reconhecimento da nulidade do ato processual imperfeito e que faz com que esse ato imperfeito seja juridicamente insubsistente, decorre de ofensa às garantias do contraditório e ampla defesa, bem como do comprometimento da correção e justiça do julgamento que se apoiará no material produzido durante o processo ${ }^{54}$. Mas não se exige que o prejuízo sempre seja demonstrado minuciosamente nos autos para que a nulidade seja decretada, sendo que muitas vezes essa demonstração se faz "através de simples procedimento lógico,

51 Nesse sentido, "é nula a sanção que não foi precedida de regular procedimento administrativodisciplinar" (SUPERIOR TRIBUNAL DE JUSTIÇA, RMS 7.449/MA, rel. Min. Anselmo Santiago, julgado em 24.11.97, DJU-I 30.03.98). Aliás, "cumpre ter presente que o Estado, em tema de puniçōes de índole disciplinar ou de caráter político-administrativo, não pode exercer a sua autoridade de maneira abusiva ou arbitrária, desconsiderando, no exercício de sua atividade censória, o princípio da plenitude de defesa, pois - não custa enfatizar -, o reconhecimento da legitimidade ético-jurídica de qualquer sanção punitiva imposta pelo Poder Público exige, ainda que se cuide de procedimento meramente administrativo $\left(\mathrm{CF}\right.$, art. $\left.5^{\circ}, \mathrm{LV}\right)$, a fiel observância do princípio do devido processo legal, consoante adverte autorizado magistério doutrinário" (SUPREMO TRIBUNAL FEDERAL, Ação Originária 487-0/AM, rel. Min. Celso de Mello, DJU-I 1.8.97, p. 33.523).

52 Cfe. PODER JUDICIÁRIO. Conselho da Justiça Federal. Manual do Processo Administrativo Disciplinar. Brasília: Conselho da Justiça Federal, 1990, p. 06.

53 Nesse sentido, em sede de obrigatoriedade da motivação das decisões administrativas dos Tribunais, já decidiu o Supremo Tribunal Federal que "torna-se evidente, portanto, que sanções administrativas impostas pelos Tribunais podem refletir uma situação de atipicidade constitucional, revestidas de graves consequiências no plano jurídico, pois a eventual inobservância 'do modelo, do tipo imposto pela Constituição' gera (...) a invalidade do ato estatal praticado em desconformidade com a cláusula inscrita no art. 93, X, da Lei Fundamental da República" (SUPREMO TRIBUNAL FEDERAL, AO 487/AM, rel. Min. Celso de Mello, julgado em 10.07.97, DJU-I 01.08.97, p. 33.523).

54 Cfe. GRINOVER, Ada Pellegrini; FERNANDES, Antonio Scarance; e GOMES FILHO, Antonio Magalhães. As nulidades no processo penal. São Paulo: Malheiros, 1992, pp. 23-24. 
verificando-se a perda da faculdade processual conferida à parte ou o comprometimento dos elementos colocados à disposição do juiz no momento da sentença tiveram influência no resultado final do processo", sendo que "as nulidades absolutas não exigem demonstração do prejuízo, porque nelas o mesmo é evidente" 55 .

Por exemplo, no caso da autoridade processante negar ao magistrado-acusado seus direitos de interrogatório pessoal, de inquirição de testemunhas, de presença na sessão de julgamento, de sustentação oral etc, então manifesta e inequivocamente estarão negados o contraditório e a ampla defesa do magistrado-acusado, sendo aí evidente o prejuízo e cerceamento à sua defesa, que importa a nulidade do respectivo ato, salvo se do julgamento tiver resultado a total e absoluta improcedência da acusação e o reconhecimento da inocência do magistrado-acusado (isto é, não-aplicação de sanção disciplinar). Do contrário, "qualquer contrariedade à garantia de ampla defesa do acusado administrativo, seja no plano normativo, seja no nível executivo, acarreta a inconstitucionalidade do ato" ${ }^{56}$.

\section{IX - Fim das sessões secretas}

O processo disciplinar contra magistrados foi tratado pela Lei Orgânica da Magistratura, numa época em que não estava ainda vigente a Constituição Federal de 1988 e na qual a sociedade brasileira ainda não tinha o grau de amadurecimento político e institucional que hoje se verifica. Por isso, ainda se encontram previstas certas regras que não são mais condizentes com os tempos atuais, em que se busca viver na plenitude de um Estado Democrático de Direito e onde se busca o reconhecimento de que toda a Administração Pública, inclusive o Poder Judiciário, está sujeita aos princípios democráticos de direito e ao dever de bem-servir o povo brasileiro $^{57}$.

Nesse contexto, por exemplo, é que se compreende a previsão de segredo e sigilo que naquela época distante e sombria cercava a apuração de faltas funcionais dos magistrados e fazia com que então fossem secretas as questões pertinentes ao descumprimento dos deveres do cargo judiciário. Os arts. $27, \S 6^{\circ}, 40$ e 44 da LOMAN, a pretexto de protegerem o magistrado-acusado, acabavam subtraindo da sociedade o democrático direito de conhecimento das razões de Estado e de publicidade no tocante a todas as atividades administrativas que digam respeito à coisa pública. Aquilo que deveria existir tão-somente para resguardar a independência e dignidade do Poder Judiciário (art. 40 da LOMAN), acabou por se transformar num

55 Cfe. GRINOVER, Ada Pellegrini; FERNANDES, Antonio Scarance; e GOMES FILHO, Antonio Magalhães. As nulidades no processo penal. São Paulo: Malheiros, 1992, p. 24.

56 Cfe. FERREIRA, Sérgio de Andréa. A garantia da ampla defesa no direito administrativo processual disciplinar. Revista de Direito Público, ano V, volume 19, janeiro a março de 1972, p. 67.

57 Cfe. MELE, Vittorio. La responsabilità disciplinare dei magistrati. Milano: Giuffrè, 1987, pp. 02-03. 
instrumento que facilita a impunidade de quem deveria ser punido e que permite a perseguição política daqueles que tentam manter sua dignidade e independência funcional. Ao invés de perseguir os culpados e proteger os inocentes, o segredo permite justamente o contrário.

Mesmo que o art. 93-IX da CF/88 queira públicos todos os julgamentos do Poder Judiciário e o art. 37. caput da CF/88 submeta a atuação administrativa dos Tribunais à plenitudade do princípio da publicidade, ainda assim se insiste em que continuem secretas as questões pertinentes ao processo e aplicação de penalidades disciplinares aos magistrados, subtraindo da sociedade e dos demais interessados o controle e fiscalização da atividade censória dos Tribunais.

A transparência na atuação administrativa dos Tribunais, especialmente no tocante ao controle censório de magistrados, devolveria ao Poder Judiciário a confïança do povo brasileiro, que então poderia atuar como um físcal da correção e justeza na apuração e aplicação de sanções disciplinares àqueles magistrados que efetivamente deixem de cumprir os deveres de seu cargo e pratiquem infrações que, à luz do direito e da justiça. mereçam reprimenda.

Se a parte conhecer o magistrado e a conduta funcional do magistrado que julga sua ação, então ficará mais fácil para ela controlar eventuais desvios de finalidade ou abusos de autoridade, porque a eventual publicidade de uma punição não reduz a autoridade do juiz ${ }^{58}$, mas o segredo do resultado de um processo certamente compromete a imagem do próprio Judiciário e cria a idéia de impunidade, na oportuna lição do Senador Paulo Souto, por ocasião da CPI do Judiciário:

"os trabalhos da CPI mostram claramente uma faceta muito grave do Judiciário: a enorme capacidade de esconder seus problemas, sob a alegação de que nada seria pior do que a sua exposição, pelos prejuízos que isso traria com a generalização. É esta disposição a responsável pelo não funcionamento de todos os instrumentos, ainda que precários, de fiscalização do Poder, que se junta naturalmente a uma legislação que trata os magistrados como se fossem imunes a todos os desvios de comportamento. desde os meramente profissionais, relacionados à competência e à dedicação, até aqueles de natureza ética ou moral. E tudo isso se completa com um sentimento corporativo inibidor de qualquer atitude mais decidida, quando se

58 Nesse sentido, “uma questão importante é saber se a revelação pública de que um juiz foi punido pelo órgão dirigente da magistratura reduz a autoridade de suas decisões. A resposta a essa indagação é negativa, por vários motivos. Antes de tudo, o juiz decide como órgão do Estado e não como pessoa, o que significa que sua decisão é impessoal, não devendo ter qualquer importância o nome ou a individualidade do juiz. Em segundo lugar, é tempo de desmistificar a pessoa do juiz, em seu próprio benefício. É tempo de se reconhecer que o juiz é um ser humano e como tal sujeito a imperfeições. Se o juiz cometeu um erro deve sofrer uma penalidade, valendo para ele o pressuposto de que, cumprida a punição, ele reconquista a situação anterior. aperfeiçoado pelo efeito educativo da penalidade" (DALlARI, Dalmo de Abreu. O Poder dos Juízes. São Paulo: Saraiva, 1996, p. $151)$. 
trata de investigar ou de punir magistrados que não se mostrem dignos de sua função" s9.

Além disso, o controle interno da magistratura tem se mostrado ineficaz e moroso, incapaz de assegurar à sociedade brasileira um Poder Judiciário à altura da democracia que se pretende construir. É então necessário um controle externo das atividades administrativas dos Tribunais, por intermédio da ampla publicidade, da imprensa, da opinião pública, dos mais variados setores da sociedade civil etc. ${ }^{60}$ Quanto mais públicos forem os procedimentos, mais garantia se terá de uma efetiva fiscalização por todos os agentes sociais, ficando então o Judiciário menos infenso aos caprichos e à vontade particular de alguns, afastando-se o risco de que esses poucos comprometam a lisura da grande maioria ${ }^{61}$.

Somente a transparência na condução dos assuntos administrativo-disciplinares de um Tribunal é que seria capaz de impedir a manipulação da opinião pública em detrimento da seriedade e imparcialidade do serviço judiciário, além de conseguir assegurar à sociedade uma prestação jurisdicional condizente com o regime democrático. Somente quando um Tribunal não tem medo de discutir suas questões internas à luz da opinião pública é que se dissipa na população aquela sensação de impunidade e subjetivismo que podem comprometer a dignidade e o respeito da população por sua magistratura ${ }^{62}$.

59 Cfe. SOUTO. Paulo. Síntese do Relatório Final da CPI sobre o Poder Judiciário. Brasília: Senado Federal, 2000, p. 536, grifou-se.

60 Nesse sentido, "o exame de poucos casos durante os trabalhos da CPl do Judiciário foi suficiente para mostrar a extrema gravidade do momento atual da Justiça Brasileira. Como era de se esperar, a exposição do funcionamento do Judiciário revelou em toda a sua intensidade que esse Poder sofre dos mesmos males que afetam outros segmentos de nossa sociedade e que, por isso mesmo, não se justificaria que não se submetesse ao controle social indispensável ao seu funcionamento a serviço de nossa população" (SOUTO, Paulo. Sintese do Relatório Final da CPI sobre o Poder Judiciário. Brasília: Senado Federal. 2000, p. 535. grifou-se).

61 Nesse sentido, " o fato. entretanto, é que o Judiciário tem vícios, alguns tradicionais, que reduzem o alcance de sua contribuição. A par disso, é preciso lembrar que os juízes são seres humanos e como tais sujeitos a fraquezas e paixões, que muitas vezes os impedem de fázer uma autocrítica serena e objetiva" (DALLARI. Dalmo de Abreu. O Poder dos Juízes. São Paulo: Saraiva. 1996. p. 161).

62 Nesse sentido, a sempre lúcida lição de Dalmo de Abreu DALLARI: "No caso da magistratura, antes de tudo é de interesse público o conhecimento de eventual falta cometida por um juiz, sobretudo pela influência social que os juízes exercem e porque existe a convicção generalizada de que todos os juizes são plenamente confiáveis em todas as circunstâncias. Acrescente-se, ainda, que existe hoje uma exigência de moralidade e de publicidade que atinge todos os setores públicos. A obstinação do Poder Judiciário em ocultar no todo ou em grande parte suas práticas administrativas vem alimentando a suspeita de que coisas graves estäo sendo ocultadas do povo. Por todos esses motivos. a democratização sob esses aspecto será benéfica em termos de enquadramento do Judiciário nos princípios democráticos consagrados pelas modernas Constituições, mas também para melhoria da imagem da magistratura, pondo por terra o argumento de que ela utiliza o sigilo ou o autocontrole como escudos para ocultação de práticals condenáveis e de privilégios corporativos" (DAllaRI, Dalmo de Abreu. O Poder dos Juizes. São Paulo: Saraiva, 1996. p. 151, grifou-se). 
Recentemente, o Superior Tribunal de Justiça reconheceu a importância da publicidade na condução de seus assuntos administrativo-disciplinares, tendo dado exemplos de ética, democracia e civismo ao expor os assuntos do Tribunal ao conhecimento público, sem que isso venha a diminuir a confiança que o povo brasileiro deposita nas suas instituições ${ }^{63}$. Ao contrário, a transparência não faz mal a nenhuma instituição, apenas a fortalece.

Felizmente, a Reforma do Judiciário, oxigenando esse Poder da República e criando novos mecanismos de controle, decretará de vez a abertura das sessões dos Tribunais e impedirá as decisões secretas no tocante às questões administrativo-disciplinares, estando em vias de aprovação uma nova redação para o art. 93-X da $\mathrm{CF} / 88$, prevendo que "as decisões administrativas dos tribunais e do Conselho Nacional de Justiça serão motivadas e em sessão pública, sendo as disciplinares tomadas pelo voto da maioria absoluta de seus membros" ${ }^{64}$. Não será deixado espaço para que o princípio da publicidade do art. 37 , caput da $\mathrm{CF} / 88$ seja esquecido pelo Judiciário quando atua no âmbito administrativo.

Por essas razões, somente o fim das sessões secretas nos Tribunais e do segredo nos processos administrativo-disciplinares instaurados contra magistrados assegurará à sociedade que conheça seus magistrados e possa também ela velar pela lisura, imparcialidade e celeridade na respectiva atividade correcional pelos Tribunais, que o autogoverno do Judiciário exige (art. 96-I-b da CF/88), mas que não pode significar afastamento do princípio da publicidade e privação da sociedade e demais atores sociais quanto ao conhecimento das razões da Administração numa democracia que se quer participativa e justa.

63 Nesse sentido, num breve apanhado do noticiário recente veiculado na imprensa nacional, destacam-se, a título exemplificativo: (a) NOTÍCIAS DO SUPERIOR TRIBUNAL DE JUSTIÇA. Comissão conclui que não há indícios de envolvimento de servidora em fatos noticiados. Edição do Superior Tribunal de Justiça em 11.03.03. Disponivel em: 'www.stj.gov.br'. Acesso em: 12.03.03; (b) NOTÍCIAS DO SUPERIOR TRIBUNAL DE JUSTIÇA. STJ instaura comissão de sindicância para apurar denúncias publicadas na Imprensa. Edição do Superior Tribunal de Justiça em 10.02.03. Disponivel em: 'ww'w.stj.gov.br'. Acesso em: 05.03.03: (c) NOTíCIAS DO SUPERIOR TRIBUNAL DE JUSTIÇA. Operação Dilúvio: Ministro da Justiça determina instauração de inquérito pedido por Vidigal. Edição do Superior Tribunal de Justiça em 28.02.03. Disponível em: 'www.stj.gov.br'. Acesso em: 05.03.03; (d) NOTÍCIAS DO SUPERIOR TRIBUNAL DE JUSTIÇA. Advogado de Vicente Leal recebe relatório da Comissão de Sindicância. Edição do Superior Tribunal de Justiça em 28.02.03. Disponível em: 'www.stj.gov.br'. Acesso em: 05.03.03; (e) NOTÍCIAS DO SUPERIOR TRIBUNAL DE JUSTIÇA. Comissão propõe abertura de processo administrativo e afastamento de Vicente Leal. Edição do Superior Tribunal de Justiça em 26.02.03. Disponível em: 'www.stj.gov.br'. Acesso em: 05.03.03; (f) NOTÍCIAS DO SUPERIOR TRIBUNAL DE JUSTIÇA. Edson Vidigal acaba com segredo de justiça em processo contra desembargador do Rio. Edição do Superior Tribunal de Justiça em 28.01.03. Disponível em: 'www.stj.gov.br'. Acesso em: 05.03.03.

64 É essa, pelo menos, a redação após a votação das emendas de Plenário pela CCJR, na PEC 29/00 no Senado e 96/92 na Câmara (ASSESSORIA PARLAMENTAR DA ASSOCIAÇẢO DOS MAGISTRADOS DO BRASIL. Reforma do Judiciário - PEC 29/00 (96/92 na Câmara). Disponivel em: 'Www.amb.com.br'. Acesso em: 05.03.03). 
A gestão administrativa dos Tribunais precisa ser transparente, sem véu nem mistério. $O$ espaço em que o Judiciário atua não é privado, mas público. Todos devem fiscalizá-lo, valendo aqui a lição de Immanuel KANT, para quem todas as ações relacionadas com os direitos dos outros homens são injustas se incompativeis com o princípio da publicidade ${ }^{65}$. Ou seja, o que não pode ser às claras discutido nos tribunais, não pode ser discutido nos tribunais.

É momento, portanto, de empunharmos a bandeira da publicidade e da transparência nas instituições democráticas, buscando o fim do segredo quanto aos processos administrativo-disciplinares, que somente contribui para que as falhas da administração da justiça e dos próprios magistrados permaneçam sob o tapete, ao invés de serem definitivamente purgadas. Não basta sermos honestos, é preciso também parecermos honestos. Só a transparência em todos os assuntos permite essa prova.

65 Nesse sentido, "all actions relating to the rights of others are wrong if their maxim is incompatible with publicity" (KANT, Immanuel. Practical Philosophy. Cambridge: Cambridge University Press, 1996, p. 347). 


\section{Curso de Prática Forense Cível e Comercial}

José de Souza Gama

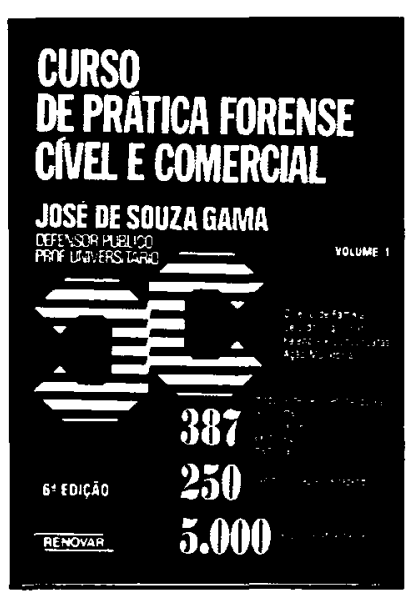

O leitor encontrará nesta obra vinte capítulos didaticamente dispostos, objetivando facilitar o ensino do professor e a aprendizagem do alunado. Cada capítulo é composto basicamente de texto legal, da hipótese (modelo), da jurisprudência e dos exercícios. Seguindo a estrutura do vigente Código de Processo Civil, será encontrada uma série de exercícios que se referem aos casos diários do advogado, e, ao praticá-los, estará aprendendo.

$\begin{array}{lll}\text { Ref. } 0040 & \text { Cartonado } & 2 \text { vols. } \\ 1.692 \text { págs. } & \text { Form. } 16 \times 23 & 1996-6^{\mathrm{a}} \text { ed. }\end{array}$

\section{Curso de Prática Forense Penal}

José de Souza Gama

Esta obra tem como objetivos básicos facilitar o ensino, a aprendizagem e prática, usando o método "Aprenda fazendo". Os exercícios são criativos, variados, estimulantes, e a maior parte já foi testada em sala de aula, com excelente resultado. A obra segue rigorosamente a ordem estabelecida no vigente Código de Processo Penal.

Ref. 0026

Form. $16 \times 23$
Cartonado 1999
950 págs. $13^{\mathbf{a}}$ ed.

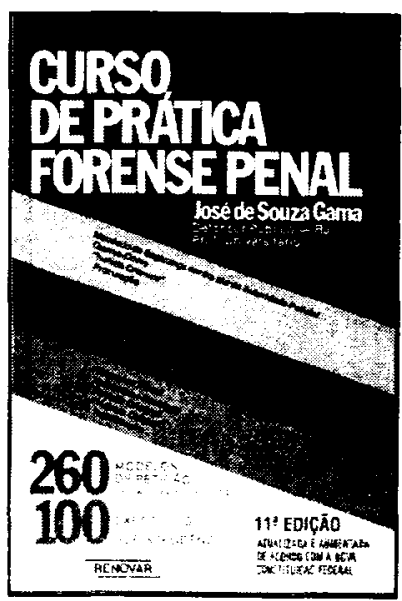

